University of Nebraska - Lincoln

DigitalCommons@University of Nebraska - Lincoln

Chinese fisheries enforcement: Environmental and strategic implications

Lyle J. Goldstein

U.S. Naval War College, lyle.j.goldstein@gmail.com

Follow this and additional works at: https://digitalcommons.unl.edu/usnavyresearch

Goldstein, Lyle J., "Chinese fisheries enforcement: Environmental and strategic implications" (2013). U.S. Navy Research. 33.

https://digitalcommons.unl.edu/usnavyresearch/33

This Article is brought to you for free and open access by the U.S. Department of Defense at DigitalCommons@University of Nebraska - Lincoln. It has been accepted for inclusion in U.S. Navy Research by an authorized administrator of DigitalCommons@University of Nebraska - Lincoln. 


\title{
Chinese fisheries enforcement: Environmental and strategic implications ${ }^{\text {tr }}$
}

\author{
Lyle J. Goldstein ${ }^{\mathrm{a}, \mathrm{b}, *}$ \\ a China Maritime Studies Institute, U.S. Naval War College, Newport, RI, United States \\ ${ }^{\mathrm{b}}$ Watson Institute for International Studies, Brown University, Providence, RI, United States
}

\section{A R T I C L E I N F O}

\section{Article history:}

Received 30 March 2012

Received in revised form

11 December 2012

Accepted 12 December 2012

Available online 21 February 2013

\section{Keywords:}

China

Fisheries enforcement

Maritime disputes

South China Sea

East China Sea

Yellow Sea

\begin{abstract}
A B S T R A C T
In almost all of the maritime territorial disputes in East Asia, fisheries questions play a significant role. One need only consider that fishing has been at the heart of serious wrangling among East Asian states from the Yellow Sea, through the East China Sea, and down to the South China Sea in recent years. Chinese fisheries policy might be critical to the possibilities for peaceful resolution of the many maritime territorial disputes in East Asia. Moreover, China's status as the world's largest fishing power also means that Beijing's inclination to accept and practice global fisheries norms could mark a giant step forward for environmental protection of the oceans in the coming century. Drawing on a wide array of unique Chinese Mandarin-language sources, this study seeks to explore the often noted "implementation gap" in Chinese fisheries enforcement practices. The study reveals that Beijing is making gradual and earnest efforts to comply with international environmental norms with respect to fisheries. That is a positive development for the health of the world's oceans, but some of these same policies may also have the impact of aggravating tense maritime disputes in the region as well.
\end{abstract}

(c) 2013 Published by Elsevier Ltd.

\section{Introduction}

New strains in East Asia reflect geopolitical maneuvering in a landscape altered, above all, by the steady and dramatic rise of China over the last three decades. The maritime domains of East Asia are developing as areas of acute tension, because this is where great powers and also smaller states come into regular contact, the legal principles to regulate their conduct are somewhat ambiguous, and also because of the considerable resources at stake. In almost all of the maritime territorial disputes in East Asia, fisheries questions play a significant role.

One need only consider that fishing has been at the heart of serious wrangling among East Asian states from the Yellow Sea, through the East China Sea and down to the South China Sea over this past year. In December 2011, a Chinese fisherman killed a South Korean Coast Guardsman, rocking a relationship that has been troubled since at least the spring 2010 sinking of the South Korean frigate Cheonan [1]. In September 2010, another fishing incident sparked a dramatic crisis between China and Japan. After the Japan Coast Guard arrested a Chinese fisherman for seemingly reckless navigation practices near the disputed Senkaku/Diaoyu islands, Beijing is alleged to have threatened Tokyo with a cut-off

\footnotetext{
* Corresponding address: China Maritime Studies Institute, U.S. Naval War College, Newport, RI, United States. Tel.: +1 401441 0093; fax: +1 4018414161.

E-mail address: lyle.j.goldstein@gmail.com

CAVEAT: This paper represents the findings and opinions of the author and does not reflect the official assessment of the U.S. Navy or any other agency of the U.S. Government.
}

in supplies of critical rare earth minerals-a major shock to the bilateral relationship [2]. During 2012, Chinese fisheries cutters appear to have increased patrols in the disputed East China Sea claim area. Moreover, fisheries has been raised as a key issue dividing the many disputants of the South China Sea and has indeed played a conspicuous role in the on-going crisis that erupted in spring 2012 between China and the Philippines regarding Huangyan Island/Scarborough Shoal.

The above list of troubling episodes strongly suggests that Chinese fisheries policy might be critical to the possibilities for peaceful resolution of the many maritime territorial disputes in East Asia. Moreover, China's status as the world's largest fishing power also means that Beijing's inclination to accept and practice global fisheries norms could mark a giant step forward for environmental protection of the oceans in the coming century. With both strategic and also environmental concerns in mind, therefore, this paper endeavors to evaluate China's efforts to regulate its marine fisheries, to discuss the future prospects and challenges for this regulation and finally to outline various implications of this effort.

\section{Materials and methods}

Chinese fisheries experts are active in global fisheries and maritime policy fora and they have collectively sought to offer English-language readers a window into Chinese fisheries management and various related challenges. In their important 2008 article in Marine Policy, for example, researchers Yu Huiguo and Yu Yunjun noted China's "overexploitation and misuse of marine 
coastal resources as well as marine pollution" [3]. Among the methods that they highlighted in Beijing's efforts to try to address this dismal situation, included: (1) the fishing license system, (2) the mid-summer fishing moratorium, (3) the "zero growth" policy, (4) limitations on fishing-boat size, (5) a fishing boat scrapping program and (6) initiatives to combat illegal, unreported and unregulated (IUU) fishing. That important article by $\mathrm{Yu}$ and $\mathrm{Yu}$ offers crucial insights into these many aspects of the Chinese fisheries challenge, but as in many analyses by mainland Chinese authors, the paper makes no mention of the many international conflicts that are closely connected to fisheries in East Asia.

This paper will not only seek to update the good scholarship by $\mathrm{Yu}$ and $\mathrm{Yu}$, but also to integrate a discussion of Chinese fisheries practices within a wider regional context where serious international disputes are regrettably the norm. The present effort will, moreover, focus on what Yu and Yu term the "implementation gap"-namely the problem of Chinese fisheries enforcement practices. As such, the narrow institutional focus of this paper is on the Chinese Fisheries Law Enforcement Command (FLEC), which is part of the Bureau of Fisheries Management within the Chinese Ministry of Agriculture. This manuscript draws upon a host of rather unique sources_including a wide variety of writings in Mandarin Chinese. Of these materials, the most important to note is the 中国渔业年鉴 2010 [China Fisheries Yearbook 2010]. This annual report of the Agriculture Ministry in China suggests that the Chinese government is more transparent that many realize. Given the immense ecological and strategic importance of these issues and the wide availability of such materials, this article may serve to spark the interest of foreign scholars to closely examine Chinese fisheries enforcement practices and thus encourage peaceful and environmentally sustainable solutions to the various regional maritime disputes.

\section{Background}

Before endeavoring to paint a fuller picture of the present situation in Chinese fisheries, it will be worthwhile to briefly present some background, especially focusing on developments of the last two decades. In addressing the issue of fisheries management, one should note that that from the earliest days of the PRC, the escort of China's fishing fleets was viewed as a core mission of the Chinese Navy [4]. In the aftermath of the devastating Cultural Revolution, the Chinese Navy began to consider more ambitious tasks and state institutions (including the armed forces) were generally reduced in capacity, in part to facilitate the growth of private entities. As originally developed in the 1970s, the fisheries service actually reported directly to both the State Council and also the Central Military Commission, reflecting the long-held belief that marine fisheries issues constituted a national security problem for China [5].

Regulatory neglect ensued as a strong emphasis was placed on ever-increasing production targets. For Chinese fisheries, the new and relentless pursuit of profit put in place by Deng Xiaoping resulted in a massive expansion in Chinese fishing effort and catch. In 1985, China entered the realm of the fishing powers by launching its first fleet of long-distance fishing vessels [6]. This dramatic growth in effort resulted in an almost fivefold increase in marine fisheries catch by 2000 .

While fisheries protection efforts in the PRC go back as far as 1955 when a trawler restricted line was established by the State Council, it is also clear that many of the positive, preliminary steps toward conservation were ignored during the headlong rush for economic growth of the 1980s and early 1990s. A major shift occurred in the late 1990s with Beijing adopting a series of important reform measures, including the inauguration of the summer fishing ban in the Yellow and East China Seas in 1995, the adoption of an explicit policy to favor aquaculture while "stabilizing" marine fisheries in 1996, as well as new fisheries agreements with Japan in 1997 and South Korea in 1998. The most important step in this reform process, however, appears to be the "zero growth" plan to control fishing capacity adopted in 1999, along with a measure to spread the summer fishing bans to both the Bohai and also the South China Sea (including notably both Hong Kong and Macau). With respect to enforcement capacity, the China Maritime Surveillance (CMS) was created in 1998 with the mission, closely related to fisheries enforcement, of protecting China's extensive Exclusive Economic Zone (EEZ) from various forms of encroachment. In 2000, a Fisheries Law Enforcement Command (FLEC) center was established "in order to bring Chinese fisheries management in line with international standards and to meet domestic needs for the centralization of fisheries management" [7]. Other achievements of this period of reform included: a fisheries agreement with Vietnam, the extension of fishing bans to parts of the Yangtze River, and also an ambitious effort to create marine protected areas [8].

It is not certain at this point what leaders or bureaucratic constellation enabled the above sweeping reforms, but one may speculate that - as elsewhere in global fisheries - that a deep crisis in the form of depleted stocks likely spurred the above actions. The kind of data at the heart of this crisis included the revelation that since the 1960s, fish species in the Beibu Gulf (Gulf of Tonkin) area of the South China Sea had declined from 487 to 238. The same study revealed that stock density had reached its lowest level in 1998 at just $16.7 \%$ of that compared to the level of 1962 [9]. Suggesting that the crisis would not be easily remedied, Chinese fisheries expert Prof. Mu Yongtong wrote in 2006: "Now, the fact is obvious that the development of our nation's fishing industry has reached an extremely important juncture. Most - if not all - of the fisheries have been fully exploited, and many are already exhausted" [10].

A different perspective on this crisis emerges from a study by faculty of the Maritime Police (China Coast Guard) Academy in Ningbo that was published in 2007 and which received ample attention in diverse parts of the Chinese government. The authors asserted that Chinese fisheries suffered from significant foreign encroachment, explaining that, for example, fishermen from Malaysia, Vietnam and the Philippines were taking advantage of the summer time ban on Chinese fishermen in the South China Sea to take a larger catch for themselves [11]. The authors maintained that part of China's problem in fisheries enforcement was related to the division of labor in maritime enforcement among "five dragons stirring up the sea," rather than the centralized enforcement (e.g. coast guard) wielded by states such as Japan or the United States. As an illustration of the problem, the Ningbo Academy faculty suggest the apparently common place problem in Chinese maritime enforcement of “管得着的看不见, 看得着的管不了” [Jurisdiction without visibility versus visibility without jurisdiction] [12]. In other words, the balkanized nature of Chinese maritime enforcement into at least five different departments, of which the FLEC of the Agriculture Ministry is just one major entity and not at all the most potent, has seemingly contributed to the present crisis in Chinese fisheries and the weakness of fisheries enforcement.

\section{Results}

Before describing the current situation of Chinese fisheries enforcement, it will be useful to review the current data regarding the state of Chinese marine fisheries activity from the China Fishing Yearbook 2010. Wider discussion of this data by global 
fisheries experts and marine scientists may result in a better understanding of Pacific fisheries conditions more generally.

\subsection{Chinese Fisheries data}

The total marine catch for 2009 was $11,786,109 \mathrm{t}$, up $2.5 \%$ from 2008. The catch of pelagic fishes for 2009 was reported to be $8,040,286 \mathrm{t}$, up $1.8 \%$ from 2008 . The take of shellfish for 2009 was reported as 2,018,924 t, up 3.8\% from 2008 [13]. Among the three basic regions encompassing Chinese fisheries, the East China Sea yielded the largest catch, followed by the Bohai/Yellow sea areas, and with the South China Sea somewhat lower than these other areas. While each of these sea areas registered higher catches, it is interesting to observe that the South China Sea area witnessed the smallest increase of .4\% [14]. Measured by earnings, the provinces of Zhejiang, Shandong and Fujian were by far the largest in that order in the marine fisheries sectors [15]. It is also worth noting that countrywide and including aquaculture, fishermen from these same provinces also brought home some of the highest salaries when compared to other provinces [16].

Breaking down further the catch of pelagic fish by Chinese fishermen, the largest catch for 2009 by significant margin was of hairtail at $1,172,440 \mathrm{t}$, a slight decline from 2008. Blue round carangid, anchovy, Spanish mackerel, silver pomfret and small yellow croaker followed in that order, varying between 350,000 and 550,000 t. However, the largest catch increases did not involve any of those large fisheries. Rather, major catch increases were of mullet, porgy, spotted maigre, black scraper, and sand lance-all of which increased $10-20 \%$ in 2009. The largest catch declines for 2009 were of bamboo pod fish, chub mackerel, anchovy, and pacific herring. The decline for anchovy amounted to $-20.8 \%$ [17].

With respect to shellfish, the large shrimp catch was up 5.6\% in 2009 , rising to a total of $1,475,426 \mathrm{t}$. The crab catch was down slightly to $543,498 \mathrm{t}$. The squid catch increased slightly to $351,778 \mathrm{t}$ in 2009. Prawns were reported to increase the most (20\%), while the take of algae saw the steepest decline in this reported data $(-38.75 \%)$ [18].

China was officially reported to have just over a million fishing boats, of which 672,633 are motorized and 430,835 are involved in marine fisheries, including 1570 large fishing vessels, 68,538 medium-sized fishing vessels and 360,727 small fishing boats. Despite policy intention to decrease fishing capacity, both numbers of boats and also tonnage are reported to have increased from 2008 to 2009. A few provinces, including Guangxi, Shandong and Guangdong succeeded in reducing fishing tonnage, but others such as Zhejiang and especially Jiangsu saw major increases [19]. Of the almost 11.8 million tons of marine catch landed by Chinese fishermen, nearly half were made by trawlers. The second most common fishing technique were the use of gill nets at $21.9 \%$ of the catch. Only $6.4 \%$ of the total Chinese catch was made by purse seiners.

Concerning China's distant water fishing fleet (DWF), the total catch for 2009 was reported to be $977,226 \mathrm{t}$, of which more than half was sold in foreign markets. China's DWF fleet was reported to amount to 1456 vessels, working for 108 enterprises that fish within the EEZs of 28 different countries. ${ }^{1}$ Significantly, this was a substantial decline from 2008 , lower in tonnage by $16 \%$ and in profits by $12 \%$. Such numbers do not support the contention that Beijing is "exporting" its fishing difficulties, but this data could be anomalous. Tensions with South Korea meant that no Chinese

\footnotetext{
${ }^{1}$ It Is not clear whether this official aggregate number of DWF vessels includes fishing boats that fly under flags of convenience, but one suspects that it does not, creating the possibility that official DWF numbers may substantially underestimate actual Chinese fishing effort.
}

DWF vessels were permitted to fish legally within the ROK EEZ during 2009. The Chinese DWF remained active in the Indonesian EEZ with 154 boats bringing in $140,000 \mathrm{t}$ of fish. Noting a complete withdrawal from fishing grounds proximate to Pakistan and Sri Lanka, the Chinese DWF apparently maintained its position in waters off of Myanmar, India, Malaysia, the Philippines, Thailand and Oman. The Chinese DWF continues its focus on West African waters with EEZ agreements with 10 different nations in that region. 375 Chinese fishing boats were said to have worked in West African waters in 2009, catching 190,000 t of fish. Recognizing the dilapidated condition of some of these Chinese DWF working in African waters, a number of new trawlers are being added. China's DWF effort in the Indian Ocean was apparently severely impacted by pirate activity in that region and thus suffered a 30\% decline in production [20]. The Chinese DWF apparently added five vessels to its tuna fleet that caught 165,000 $\mathrm{t}$ in 2009, an increase of $29 \%$ over 2008. This sector of the DWF appears to be most profitable, not surprisingly. 378 Chinese DWF vessels were involved in squid fishing in international waters, but there appears to be substantial turmoil in this sector as both catch and profits were down dramatically in 2009-58\% and $46 \%$ respectively. Indeed, the Chinese Fisheries 2010 Yearbook reports that North Pacific squid fisheries witnessed "an all-time historical low in production." The five provinces supporting the most DWF boats were Fujian, followed by Liaoning, Shanghai, Guangdong and Zhejiang in that order of magnitude. Of the DWF total catch tonnage, $16.9 \%$ were for tuna and $17.6 \%$ was squid [21]. One Chinese fisheries expert concluded recently that Beijing was making major efforts to better control and regulate its DWF fleet [22].

\subsection{Chinese Fisheries Law Enforcement Command (FLEC)}

The same annual report that yielded the catch data above suggests that the FLEC had 2165 enforcement vessels of all sizes in 2009 with a total force equivalent of $55,453 \mathrm{t}$. The force was reported to have lost 144 ships (3358 t) since 2008 [23]. In terms of human capital, the FLEC has 35,093 personnel. Apart from a headquarters unit of 865 persons, they are spread among all of China's provinces. Maritime provinces, such as Shandong, Guangdong and Zhejiang have the largest detachments not surprisingly, but reflecting the growing importance of aquaculture in China's national economy, inland provinces such as Jiangxi, Sichuan and Yunnan all have FLEC detachments of over one thousand personnel [24].

Illustrating an apparent consensus in the Chinese government that includes the influential military, there is a strong conviction that Chinese maritime enforcement forces are too weak, especially relative to other Pacific maritime powers [25]. The announcement in October 2010 by a senior official that China would endeavor to build 30 maritime enforcement cutters over the next 5 years was the result of this consensus [26]. Relative to other world coast guards, this rate of production qualifies as a very significant buildup that illustrates both the determination of Beijing to advance in this area, but also the relative backwardness of current forces that have long been neglected. Indeed, it has seemed that over the last decade among the so-called "five dragons" of Chinese maritime enforcement that the FLEC has ranked among the lowest of priorities. Measured by the rate of new, large cutters joining the force, the FLEC seems to have ranked well behind both the Maritime Safety Administration (MSA), the China Maritime Surveillance (CMS), or even the Border Control Department (BCD_-also known as China Coast Guard).

A recent unofficial report suggests that the FLEC has 140 ocean-going cutters with eight vessels exceeding $1000 \mathrm{t}$. This same report observes that 渔政 202 (hereafter YZ 202) was China's first modern, large enforcement cutter that entered service with 
the FLEC in 2001. This ship had upgraded inspection capabilities and longer range, as well as more advanced radar, communication and navigation equipment. In recognition of the FLEC's evident weakness in large cutters, a 4500 t Chinese Navy rescue ship was transferred to the FLEC in 2008 and has been designated as YZ 311. CMS and BCD also took over older Chinese Navy ships about the same time. In terms of speed, range and tonnage, YZ 311 certainly represented a new stage for the FLEC and apparently was immediately put to work patrolling in the more distant areas of the South China Sea [27].

Future operations and capabilities of the FLEC, however, are probably better understood by briefly examining the newest cutter - much heralded in the Chinese press - designated YZ 310 that entered service in September 2010. Its speed of 22 knots makes it the fastest cutter in service with the FLEC. The cutter is $107 \mathrm{~m}$ in length and has a crew of 56 . At $2500 \mathrm{t}$, it is certainly capable of deep ocean patrols and is said to have a range of $6000 \mathrm{~km}$. Notably, it might be the first FLEC ship to be significantly armed, as it is equipped with a pair of $14.5 \mathrm{~mm}$ rapid fire machine guns mounted on deck, which is suggested to be a response to the increasing threat of piracy. More important still is that it is the first FLEC ship to have a helicopter hangar and launching deck. Chinese maritime analysts are emphatic regarding the enforcement, surveillance and rescue value of helicopters, though aviation has traditionally been a major weakness across Chinese maritime enforcement, especially within the FLEC [28].

As in most endeavors, capital and technology are only one part of the equation and more often than not, human capital more accurately determines true capability. At present, unfortunately, little is known regarding the recruitment, education and training of FLEC personnel. Of the approximate 33,095 employees of the FLEC reported above, it is said that 5467 serve on board FLEC vessels. The FLEC apparently added 2000 additional billets during 2009. 67\% of FLEC personnel are now college graduates, up 11 percentage points compared to 2005 [29].

Similarly, there does not appear to be much public information regarding FLEC patrol patterns and operations. However, some data is available regarding ship inspections. For 2009, the FLEC claims to have performed 4971 vessel inspections, and also expelled 103 foreign fishing vessels illegally fishing in Chinese waters. Although the FLEC appeared to have moderate patrol activity, including some inspections in the vicinity of the Paracel Islands in the South China Sea, no vessel inspections were claimed in the sensitive Spratly Islands area [30]. In December 2012, new Chinese civil maritime enforcement regulations seemed mainly aimed at restricting Vietnamese fishing around the Paracels [31].

According to official data, about 300 Chinese fishermen died at sea with the most frequent causes of death being accidents resulting from collisions and also typhoon-related sinkings. The FLEC was reported to have been involved in 877 rescue incidents in 2009 in which 4502 Chinese fishermen were saved. An apparent priority for the FLEC has been to provide Chinese fishermen with advanced communication and navigation equipment to facilitate rescue [32]. A report in 2009 suggested that the government would provide two-way satellite communications equipment for one million Chinese fishing vessels [33]. The AIS system is widely functional along the Chinese coast. Satellite vessel monitoring systems are apparently in place, as well, to assist with enforcement [34].

According to the 2009 China Fisheries Yearbook, the FLEC first undertook to patrol the Spratlys region of the South China Sea in 1994 and was ready at that time to both "eat bitterness ... and to ... struggle ..." [35]. On the other hand, such long distance patrols appear to be quite rare even up until the present time in light of the major headlines accorded to the deployment of the new YZ 310 to the Spratlys region in late 2010. This vessel's deployment to that sensitive sea area at that time was apparently intended to both "regularize [and] ... institutionalize" Chinese fisheries patrolling in the Spratly's area of the southern South China Sea [36]. An even more significant clue regarding FLEC patrol patterns in the South China Sea concerns the 12 degree line, cited in at least one Chinese official pamphlet to suggest that the summer fishing ban is enforced north of that line, but not south of it [37]. This intriguing enforcement policy will be taken up again for discussion in the section that follows. Relying on Vietnamese data, as well as Chinese figures, Taylor Fravel concludes that there was a disturbing uptick in 2009 of Chinese confiscations of Vietnamese fishing boats in the South China Sea, but these numbers subsequently fell sharply in 2010 - and no cases were reported for 2011 - though an uptick may already be evident in 2012 [38]. In November 2011, it was announced that the medium-sized FLEC cutter YZ 306 would hence forth be based in the Paracel Islands [39]. This may serve as yet another indication that the FLEC will play a definite role in China's evolving strategy for the South China Sea [40]. A clear pattern of increasing FLEC patrols is evident in the South China Sea, a point noted recently by Fravel using similar data [41].

Another rather conspicuous and likely politically motivated deployment of FLEC ships occurred immediately after the confrontation with Japan in September 2010 concerning the Japan Coast Guard taking a Chinese trawler crew into custody in the East China Sea. The image of China FLEC cutters standing "eyeball to eye-ball" with Japanese Coast Guard cutters in the disputed area produced significant consternation among Chinese observers who noted that their cutters did not compare favorably either in respect to size or capabilities [42]. FLEC cutters have also been deployed with other civil maritime forces to the sensitive Diaoyu/Senkaku island dispute with increasing frequency since the fall of 2012.

While it is useful to put the analytical spotlight on the FLEC alone among Beijing's so-called "five dragons"-the multiple agencies charged with various aspects of maritime enforcement, there is also some risk of oversimplification. For example, there has apparently been substantial Chinese progress on integrating various maritime enforcement capabilities to conduct fisheries enforcement. In a couple of provinces (e.g. Guangxi), FLEC units are reported to have completely integrated with the units of China Maritime Surveillance (CMS), while in others (e.g. Liaoning), the two forces remain quite independent [43]. Since CMS is quite well manned and equipped (over 130 vessels) and by some measures (e.g. aviation/ large cutters) enjoys greater prestige and resources than the FLEC, further integration is likely to benefit Chinese fisheries management practices [44].

\section{Discussion}

\subsection{Positive outlook}

Given the trends outlined above, it is important to state that the overall picture is one of steady improvement in China's approach to fisheries management. Various and numerous problems continue to plague this system (and will be analyzed in Section 5.2), to be sure, but China is in no sense a "rogue" actor in regional and global fisheries, nor does it seem to be using fisheries issues as lever to coerce its neighbors within a scheme of maritime expansion, as has been alleged [45]. Among major fishing states, Beijing does not receive top marks for fisheries management, nor is it totally out of step with emerging maritime norms.

Beijing's general approach actually appears to be surprisingly rational in coping with a sector rife with unresolved conflict between fishermen and scientists that has frequently resulted in environmental disaster. First and foremost, the Chinese leadership has made a series of important decisions that have set China on the 
right course. These have included the mid-1990s decision to strongly emphasize aquaculture in order to take production and employment pressure off of marine fisheries. Also important have been the series of fisheries agreements that followed in that period of major reform with key maritime neighbors. Those agreements have resulted in many angry Chinese fishermen and they are perhaps by nature imperfect, requiring constant fine-tuning, but they have crucially created a strong institutional framework and enduring precedent for regional cooperation in fisheries management. The "zero growth plan" adopted in 1999 stands as a landmark decision by the Chinese leadership that cut sharply and directly against the country's national ethos of rapid and unceasing growth. In that sense, the decision may warrant further case study research for scholars interested in Chinese environmental policy. The summer fishing bans are but one of several techniques now used by Chinese regulators, attempting to reach a sustainable equilibrium in marine fisheries.

The implementation gap remains, but this paper suggests that this problem is being addressed. For example, the fact that fishing tonnage in both Shandong and Guangdong provinces (two of the largest marine fishing areas) decreased during 2008-09 appears to reflect major efforts to better regulate Chinese marine fisheries. Likewise, although the Chinese DWF fleet is active now on all the world's oceans, it is noteworthy that it declined in size during 2008-09 (the second year in a row) [46], suggesting again that Beijing is actually not simply out to exploit the world's oceans down to the last fish. An especially critical component of China's apparent commitment to improving its fisheries is its robust development and cultivation of fisheries expertise, which is readily apparent in its many ocean policy and fisheries research journals, as well as in its support of dedicated and robust research efforts embodied in such quality institutions as China Ocean University (Qingdao) or Shanghai Ocean University. Indeed, the technocratic Chinese approach to marine resources management is amply evident in the annual Chinese Fisheries Yearbook-a major source for this paper. Chinese statistics have been problematic for fisheries science in the past [47], but the data are now much more credible, reporting as they do both good news and bad. Overall, it should be recognized that the practices of Chinese fishermen have important regional and global environmental consequences and so continued strengthening of the China FLEC is a crucial process not just for Chinese but also for the world.

\subsection{Major challenges}

Despite the generally positive outlook flowing from a series of brave decisions in the 1990s, Chinese marine fisheries cannot yet be described as healthy. A few positive signs have been recorded, but overall fish stocks remain dangerously depleted and Chinese fisheries experts remain pessimistic [48]. A fall 2011 study in 渔业科学进展 [Progress in Fishery Science] is apparently not an exception, observing:

... fishing methods in 32 [Chinese] fishing ports [reveal]... trawling intensity greatly exceeds the reproduction capacity of fishery resources, and the fishing yields are of low value and immaturity, subsistence fishing and commercial fishing show ... prominent contradictions ... [but] mesh size... and net mouths are getting bigger ... seabed and benthic organisms are seriously damaged by ground wire of the beam framework trawl ... [49].

Another 2011 Chinese study found that pollution was a significant reason that Bohai fish production is now just $20 \%$ of the level as recently as the 1980s [50]. Three fundamental problems remain, consisting of both institutional and practical difficulties, as well as international issues (discussed in the section to follow).

As discussed previously, a consensus among Chinese maritime analysts holds that China's approach of multiple maritime enforcement agencies without any single "leading dragon" has created a problematic situation of confusion, inefficiency and general weakness. While some significant steps toward realizing integration among the maritime enforcement agencies have been achieved, the outlook is not especially promising in this regard. For example, the phenomena described in Section 4 above of various provinces integrating maritime enforcement while others do not, is broadly suggestive of the pervasive decentralization in Chinese maritime enforcement that inhibits uniform and effective fisheries management. Moreover, despite some improvements in both personnel and capital, it seems that the development of the FLEC is not a very high priority - well behind the robust Maritime Safety Administration (MSA), for example. Explaining recent fishing tensions between the ROK and China in the Yellow Sea, Chinese fisheries experts suggest that ROK enforcement is better, but also that their respective problem turns out to be significantly easier, since China's fishing fleet is more numerous and lowtech-posing a continuing enforcement challenge for the China FLEC.

Despite stricter enforcement measures and a variety of measures discussed above, major problems may continue to exist within the mechanics of Chinese enforcement. Thus, a recent report in the Chinese journal 海洋发展与管理 [Ocean Development and Management] notes that four of five critical fish species stocks off of Guangdong show no improvement under the current regime of regulation [51]. The summer fishing ban, perhaps China's most fundamental control on fishing effort, is controversial. One study, for example, claims that the summer ban is more effective than restrictions on mesh size and that significant improvements followed the 2009 decision to extend the ban from 12 weeks to 14 [52]. Other Chinese specialists, however, argue that the summer ban fuels regional tensions (see Section 5.3 below) and needs to be replaced by a more advanced system of tradeable quotas-a practice gaining acceptance among global fisheries experts. Without quotas in place (and related measures), it is reported that China has done little to track bycatch in its fisheries-a veritable gaping hole in its effort to restore ecological balance in its proximate seas [53]. Chinese specialists are also very concerned about the increasing and somewhat unpredictable impact of mariculture on coastal ecosystems [54]. Another concern articulated by Chinese specialists concerns the issue of 三无 [three nils] or illegal, unregulated and unreported (IUU) fishing. It is suggested that Chinese law and fishing agreements do not pay adequate attention to the problem of IUU fishing. As a specialist from Guangdong Ocean University recently notes, the problem of IUU fishing may aggravate international tensions, especially because IUU fishing activity often seeks to exploit the enforcement seams in and around international maritime boundaries [55].

\subsection{Disputes}

The fisheries issue brings together a number of different questions related to China's rise in the Asia-Pacific region in a potentially volatile mixture. These questions include China's rapid economic and naval development, its massive appetite for resources, its somewhat unhurried embrace of global environmental norms, and most of all the ambiguous nature of conflicting claims all around China's maritime periphery. Some of these maritime territorial disputes encompass natural resources chiefly oil and gas - that perhaps far outweigh the profits linked to fisheries exploitation. But the fisheries issues still come naturally to the fore because these profits are not in the distant 
future but in the here and now, and because they involve jobs among a vocal and often influential minority.

There is little doubt that recent tensions, mixing with bitter historical memories and jealousies may combine to spawn a dangerous "fishing nationalism," in the related countries. Certainly, this phenomenon is amply evident in Chinese discourse. Thus, a recent Chinese book on "emergency management" of fisheries incidents asserts: "Although our country has signed one after another fishing agreements with neighboring states, the number of fishing industry security incidents involving foreigners has unceasingly increased ... Some countries even send warships to bump and sink our side's fishing boats..." [56]. Also troubling is the seeming tendency to deploy either fishing boats (maritime militia) and/or FLEC vessels for obviously political purposes that are only peripherally related to fisheries. Related examples including dangerous incidents with U.S. surveillance vessels in March 2009 and also fall 2012 interaction in disputed areas of the East China Sea. As recently as December 2012, the Chinese press gave ample and seemingly positive press coverage to Chinese fishing vessels accused of interfering with Vietnamese fossil fuel exploration efforts in the South China Sea [57]. While disturbing from one perspective, of course, such incidents can also be seen as reassuring in that they suggest that China is not looking to escalate such crises to the level of military confrontation.

Further complicating the matter, ““武装化”" [weaponization] has been identified as a major trend for the various components of Chinese maritime enforcement including the FLEC [58]. Even small-scale armament on the newest FLEC cutter, as described in section four, implies a rather major departure for Chinese fisheries enforcement vessels that have generally been unarmed. The same report offers detailed plans regarding how Chinese fisheries cutters might be "re-outfitted" in wartime for various combat missions including anti-submarine warfare. Such a complexion for elements of China's maritime enforcement capabilities would not be outside the norm for major coast guards, but is still suggestive of worrying trends extant in the region.

Undoubtedly, a more robust FLEC comprising a large fleet of advanced, armed cutters that wield aviation capabilities might be viewed as a looming threat by other regional claimants in the East Asian region. China is hardly disguising its intent to employ these new capabilities for enforcing maritime claims, in addition to improving fisheries management. Still, one hopeful way to approach this development is to consider a much starker alternative. Would it be better if Beijing regularly dispatched naval vessels "gray hulls" equipped with missiles to enforce its claims or perhaps the "white hulls" of the FLEC instead? Chinese maritime strategists, including within the military, seem to understand that employing civil maritime enforcement "white hulls" into volatile situations is less dangerous and escalatory than the deployment of "gray hulls." Another interesting aspect of Chinese policy concerns the $12^{\circ}$ latitude line that the FLEC apparently employs in its enforcement activities in the South China Sea strongly hints at a less extreme and more compromising approach to claims and resources by Beijing in the South China Sea. Chinese fishing vessels are escorted south of this line, but the FLEC has not taken action against foreign vessels south of the line. This seemingly pragmatic line could point the way toward an equitable division of the sea's resources on the basis of a negotiated compromise.

\subsection{Cooperation}

Even as fisheries disputes may form the "leading edge" of intensifying struggles for resources in the Asia-Pacific region, it is alternatively possible to consider how fisheries might simultaneously form one of the most pioneering and innovative aspects of bilateral and multilateral maritime cooperation in this volatile region. It is not widely known that quiet, technocratic cooperation has been on-going in this area between China and various neighbors and other important maritime powers including the U.S. for decades [59].

A successful record of fisheries cooperation between Washington and Beijing is especially noteworthy given the other tensions that have plagued the broader relationship. In 1993, a memorandum of understanding was reached between the countries to jointly act against driftnet fishing in the North Pacific, a practice prohibited by the United Nations. The memo established the innovative concept of posting a Chinese FLEC ship-rider aboard a USCG cutter in order to give the American ship the necessary jurisdiction to enforce the UN prohibition effectively. To this point the FLEC has leaned upon the superior capabilities of the USCG in cooperating to serve global environmental imperatives. China FLEC personnel and related specialists have also visited various U.S. fisheries enforcement training centers in Alaska and elsewhere. In the future, however, a more robust FLEC may become a more equal partner in this kind of cooperation, regularly dispatching one or more high endurance cutter to patrol the waters of the North Pacific. No doubt, this original form of cooperation has been supported by the broader cooperative institutional framework of the North Pacific Coast Guard Forum, enabling the USCG and various maritime enforcement agencies including the FLEC to develop essential habits of dialog and cooperation. Indeed, this forum has been so well acclaimed in the difficult circumstances of Northeast Asia that it has been suggested that a parallel and similar forum might be appropriate to tackle the challenges of maritime security in Southeast Asia as well.

Some may criticize these efforts as more symbolic than substantive, but that is not at all how such efforts are presented in Mandarin-language (i.e. for Chinese audiences) official reports wherein international exchanges and cooperation are actually prioritized, for example in the China Fisheries Yearbook 2010. Thus, the East Sea FLEC department report calls for "active development of China-ROK and China-Japan fisheries cooperation, accelerating bilateral trust ... and enhancing the exchange of information," among other objectives. It also calls for strict enforcement against violations by Chinese fishermen of the waters of neighboring countries [60]. This is consistent with provincial level FLEC reports that also highlight the benefits of close international cooperation [61]. Chinese academic fisheries experts likewise see international cooperation as critical, for example in coping with the IUU challenge. Overall, it seems that closer fisheries cooperation among disputants will be crucial to the myriad maritime disputes along China's coast.

\section{Conclusion}

In outlining both the present situation in Chinese fisheries as well as China's record in fisheries regulation efforts, this study endeavors to stimulate further research and debate on issues of pivotal importance with significant environmental and strategic implications. The conclusion of this preliminary survey of various Chinese-language materials related to fisheries, rarely examined by Western scholars, yields the tentative conclusion that significant, albeit incremental progress is occurring in Chinese fisheries enforcement practices as demonstrated by major leadership commitment, the impressive related research apparatus, clear efforts to improve the China FLEC in order to close the implementation gap in Chinese fisheries, and an evident Chinese enthusiasm for bilateral and multilateral cooperation as part of the solution to persistent fisheries problems. 
As enumerated in Section 5, major flaws are still evident in Chinese fisheries enforcement, such as tabulating and reducing bycatch, but the trend is generally positive for the global environment and deserves international support. In fact, Chinese success to date in fisheries enforcement may be somewhat similar to that of the U.S. owing to each country benefiting from relatively strong, centralized governments. By contrast, the European Union has been afflicted with various contradictions among its members in developing a common and comprehensive fisheries policy [62]. To be sure, small states in dispute with China over maritime claims will no doubt be anxious regarding a more capable FLEC that will carry the Chinese flag more frequently and on larger vessels into disputed waters. At this point, there is only quite limited evidence of Beijing pushing its fishermen and enforcement vessels into disputed zones-and this practice, while regrettable and destabilizing, is still preferable to militarization. Overall, China appears to be trying to minimize the deleterious impact of fisheries complications on relations with crucial neighbors.

Contemporary China is always looking for external models to aid in its development process. Thus, it is not surprising to find Chinese specialists puzzling over the lessons of the 18-year struggle over fisheries between the United Kingdom and Iceland in the so-called "Cod War" [63]. One may hope that a major lesson of that dispute for China is that the country with the bigger navy does not necessarily prevail in maritime disputes. However, Westerners evaluating Chinese policies in East Asian waters also need to recognize that current evidence suggests that Beijing is, as in many countries, facing a wave of discontent among fishermen, but still making gradual but earnest efforts to comply with emerging international norms regarding maritime governance.

Strategists may perhaps have legitimate qualms about enhanced Chinese fisheries enforcement capabilities, but environmentalists should be relieved to know that Beijing will exercise restraint in exploiting the resources of the world's oceans.

\section{References}

[1] Sang-hun C. Chinese fisherman kills South Korean coast guardsman. New York Times, 12 December 2011.

[2] Bradsher K. Amid tension, China blocks vital export to Japan. New York Times, 22 September 2010.

[3] Yu H, Yu Y. Fishing capacity and management in China: theoretic and practical perspectives. Mar Policy 2008;32:351-7.

[4] Swanson B. Eighth voyage of the dragon: a history of China's quest for seapower. Annapolis: Naval Institute Press; 1982 p. 221.

[5] Yin H. Development of China's littoral law enforcement force and its equipment. Shipborne Weapons 2011:18 March.

[6] China Fisheries Yearbook; 2009. p. 2 [in Chinese].

[7] Yin H. Development of China's littoral law enforcement force and its equipment. Shipborne Weapons 2011:18 March.

[8] China Fisheries Yearbook; 2009. p. 4-5 [in Chinese].

[9] Yu Y, Mu Y. The new institutional arrangement for fisheries management in the Beibu Gulf. Mar Policy 2006;30:251.

[10] Mu Y. Fisheries management: focusing on a rights-based regime. Qingdao: China Ocean University Press; 2006. p. 292 [in Chinese].

[11] He Z, Ren X, Feng S, Luo X, Liu J. Research on the creation of a Chinese coast guard. Beijing: Ocean Press; 2007 p. 54 [in Chinese].

[12] He Z, Ren X, Feng S, Luo X, Liu J. Research on the creation of a Chinese coast guard. Beijing: Ocean Press; 2007 p. 41 [in Chinese].

[13] China Fisheries Yearbook; 2010. p. 186 [in Chinese].

[14] China Fisheries Yearbook; 2010. p. 188 [in Chinese].

[15] China Fisheries Yearbook; 2010. p. 154 [in Chinese].

[16] China Fisheries Yearbook; 2010. p. 158 [in Chinese]

[17] China Fisheries Yearbook; 2010. p. 187 [in Chinese].

[18] China Fisheries Yearbook; 2010. p. 186 [in Chinese].

[19] China Fisheries Yearbook, 2010, p. 208 [in Chinese]

[20] China Fisheries Yearbook; 2010. p. 7 [in Chinese].
[21] China Fisheries Yearbook, 2010, p. 194 [in Chinese].

[22] Xue G. China's distant water fisheries and its response to flag state responsibilities. Mar Policy 2006;30:653.

[23] China Fisheries Yearbook; 2010. p. 207 [in Chinese].

[24] China Fisheries Yearbook; 2010. p. 221 [in Chinese].

[25] Sun J. Notes on maritime security in the new period of the new century. China Mil Sci 2008:77 [in Chinese].

[26] China plans to build 30 maritime enforcement cutters over the next 5 years. China News Net; 11 October 2010 [in Chinese].

[27] Yin H. Development of China's littoral law enforcement force and its equipment. Shipborne Weapons 2011:20 [in Chinese].

[28] He Z, Ren X, Feng S, Luo X, Liu J. Research on the creation of a Chinese coast guard. Beijing: Ocean Press; 2007 p. 110-20 [in Chinese].

[29] China Fisheries Yearbook; 2010. p. 26 [in Chinese].

[30] China Fisheries Yearbook; 2010. p. 118 [in Chinese].

[31] Page J. China sheds light on new sea rules. Wall Street J, 5 December 2012.

[32] China Fisheries Yearbook; 2010. p. 18-9 [in Chinese].

[33] One Million Chinese Fishermen Will Be Equipped with Two Way Satellite Communications Equipment. Xinhua Net, 22 May 2009 [in Chinese].

[34] Interviews, Qingdao, December 2011.

[35] China Fisheries Yearbook; 2009. p. 5 [in Chinese].

[36] Chen T. China fisheries enforcement vessel 310.Naval and Merchant Ships December 2010:71 [in Chinese].

[37] Yan Y. Guardian of the ocean industry: the choice for security. Hangzhou: Zhejiang Province Fisheries Law Enforcement Command; 2006. p. 23 [in Chinese].

[38] Zhang Y. Stopping Vietnam's fishing boats lawful. China Daily 201223 March.

[39] China initiated the basing of the first large fisheries enforcement cutter in the Paracel Islands. Naval and Merchant Ships 2011;(11):13 [in Chinese].

[40] Goldstein L. Chinese naval strategy in the South China Sea: an abundance of noise and smoke, but little fire. Contemp Southeast Asia 2011:3:320-47.

[41] Fravel T. Maritime security in the South China Sea and the competition over maritime rights. In: Cronin P, editor. Cooperation from strength: the United States, China and the South China Sea. Washington, DC: Center for New American Security; 2012. p. 37.

[42] Hai T. China must affix cannons as it builds Its 'second navy'. International Herald Leader, 27 November 2010 [in Chinese].

[43] Interviews, Qingdao, December 2011.

[44] Yin H. Development of China's littoral law enforcement force and its equipment. Shipborne Weapons 2011:17 March.

[45] Kato Y. U.S. commander blasts Chinese Navy's behavior. Asahi Shimbun 2010 15 June.

[46] China Fisheries Yearbook; 2009. p. 14 [in Chinese].

[47] Watson R, Pauly D. Systematic distortions in world fisheries catch trends. Nature 2001;414:534-6.

[48] Interviews, Qingdao, December 2011.

[49] Sun Z. Investigation and analysis of trawl gears in the Yellow Sea and the Bohai Sea area. Prog Fish Sci 2011;32:127 [in Chinese].

[50] Zhang X. Strategic research on the key technologies and development of China's contemporary fishing system. Beijing: China Ocean Press; 2011 p. 66 [in Chinese].

[51] Hou X. Research on the fisheries resources of the Shenzhou sea area during the hot season moratoriums of 2007-2008. Ocean Dev Manage 2009;21:111 [in Chinese].

[52] Yan L. Effect of new summer close season of trawl fisheries on fishery ecology and resource enhancement in East China Sea. Mar Fish 2010;32:185-91 [in Chinese].

[53] Interviews, Qingdao, December 2011.

[54] Interviews, Qingdao, December 2011.

[55] $\mathrm{Xu} \mathrm{H}$. Law and policy for controlling IUU Fishing. Ocean Dev Manage 2009;26:26 [in Chinese].

[56] Li Z. The ocean and the fishing industry: emergency management. Beijing: Ocean Press; 2007 p. 299 [in Chinese].

[57] Liu C, Duan C. Vietnam claims harassment by Chinese boats. Global Times 20125 December [in Chinese].

[58] Yin H. Development of China's littoral law enforcement force and its equipment. Shipborne Weapons 2011;3:24 [in Chinese].

[59] Zou K. Sino-Japanese joint fishery management in the East China Sea. Mar Policy 2003;27:125-42.

[60] China Fisheries Yearbook; 2010. p. 118-22 [in Chinese].

[61] Faithful to the law, enforcement serves the people: short report of work concerning the investigation of illegal drift nets in the North Pacific. Hangzhou: Zhejiang Province Fisheries Law Enforcement Command; 2009 [in Chinese].

[62] Clover $C$. The end of the line: how overfishing is changing the world and what we eat. Los Angeles: University of California Press; 2006 p. 320-1.

[63] Lan Y. The cod war. Modern Ships 2010:28-31 [in Chinese]. 